\title{
THE STONE-THROWING CHILDREN: THE EXPLOSION OF ANGER IN MERSIN'S SUBURBS
}

\begin{abstract}
This paper analyzes the causes of anger and violence among the children known as the "stone-throwing children" in Mersin province of Turkey. Actually, traumatic events related to the forced migration have touched the population here during the period between 1992 and 2005. Fieldwork conducted in the suburbs of Mersin (Şevket Sümer, Güneş, Gündoğdu, Siteler, Çay ve Çilek neighborhoods) with 250 children. The children throwing stones at the police are predominantly the children of these migrants. The results show that anger characterizes the children's reaction to the state. Both quantitative and qualitative methods were adopted in this research. A question form was designed and used during the in-depth interviews with the children. The respondents were tape-recorded while they completed the standardized questionnaires and were encouraged to discuss their definitions of terms and responses to items in-depth. Furthermore analyses of results were derived from statistical chi-square test.
\end{abstract}

Keywords: Anger, stone-throwing children, migration, Mersin.

\section{TAŞ ATAN ÇOCUKLAR: MERSİN'IN BANLIYÖLERINDE ÖFKE PATLAMASI}

\section{Özet}

Bu çalışma Türkiye'nin Mersin ilinde yaşamını sürdüren ve "taş atan çocuklar" olarak bilinen çocuklardaki öfke ve şiddetin nedenlerini analiz etmektedir. Aslında söz konusu travmatik olaylar, 1992 ile 2005 yılları arasındaki dönemde zorunlu göçe uğramış ve yaşamını bu bölgede sürdüren nüfusla ilgilidir. Saha çalışması Mersin'in Akdeniz ilçesi sınırları içinde yer alan Şevket Sümer, Güneş, Gündoğdu, Siteler, Çay ve Çilek mahallesinde 250 çocukla gerçekleştirilmiştir. Polise taş atan çocuklar ağırlıklı olarak, zorunlu göçe maruz kalmış ailelerin çocuklarıdır. Araştırma sonuçları göstermektedir ki öfke, söz konusu çocukların devlete ve kurumlarına tepkisini karakterize etmektedir. $\mathrm{Bu}$

\footnotetext{
${ }^{1}$ Doç. Dr., Akdeniz Üniversitesi İletişim Fakültesi, nurdanakiner@yahoo.com
} 
çalışmada kalitatif ve kantitatif yöntemler bir arada kullanılmıştır. Çocuklarla yapılan yüz yüze mülakatlarda kullanılmak üzere bir anket formu da düzenlenmiştir. Mülakatların tümü kayıt altına alınmış, anket formlarında katılımcıların ismi yerine rumuz kullanılmış ve böylece katılımcıların sorulara verdikleri yanıtların üzerinde detaylı bir şekilde durulabilmiştir. Ayrıca araştırma sonuçlarının analizi, istatistiksel Ki-Kare Testi ile de yapılmıştır.

Anahtar kelimeler: Öfke, Taş Atan Çocuk, Göç, Mersin.

\section{Introduction}

This paper analyzes the causes of anger and violence among the children known as the "stonethrowing children" in Mersin province of Turkey. This paper underlines that the children are not controllable by anyone, including their own families, contrary to the general perception about them. Actually, traumatic events related to the forced migration have touched the population here during the period between 1992 and 2005. During the period between 1992 and 2005, 3.688 rural settlements were evacuated by the policies of government (CNNTürk, 2005) leading to the forced displacement of approximately two million people (Houston, 2001:16). The last migration movement is from Eastern and Southeastern Anatolian part of Turkey in 1990's. Mersin is one of the cities that attracted the intense Kurdish migration. Those different segments of migration caused a fast increase in population. The largest wave of immigration to Mersin took place in the period 1985-1990.

Table1. Migration and Net Migration Rate in Mersin Province by Periods (TÜİK, 2005)

\begin{tabular}{llll}
\hline Periods & $\begin{array}{l}\text { Migration } \\
\text { Inflow }\end{array}$ & $\begin{array}{l}\text { Net } \\
\text { Migration }\end{array}$ & $\begin{array}{l}\text { Net } \\
\text { Migration } \\
\text { Rate (\%) }\end{array}$ \\
& & & 57.5 \\
\hline $\mathbf{1 9 7 5 - 1 9 8 0}$ & 73,699 & 40,273 & 56.5 \\
$\mathbf{1 9 8 0 - 1 9 8 5}$ & 89,444 & 49,593 & 68.3 \\
$\mathbf{1 9 8 5 - 1 9 9 0}$ & 131,573 & 74,717 & 12.4 \\
\hline $\mathbf{1 9 9 5 - 2 0 0 0}$ & 117,894 & 18,429 & \\
\hline
\end{tabular}

The children throwing stones at the police are predominantly the children of these migrants. Most of these children have not physically experienced forced migration, but they have inherited the memories from previous generations. The results show that anger characterizes the children's reaction to the state.

\section{Method of Research}

The fieldwork conducted in suburbs of Mersin with the 250 children, which indicates that the children are the children of forced migration even if some of them were not born at that time. The age bracket was limited to 7-17 years (children under seven were not interviewed, as they would not have been able to complete the standard questionnaire). Each one of the interviews conducted for this research project was undertaken with a single respondent. Because of interviewing individually, all respondents felt comfortable during the discussion of potentially 
sensitive topics. Semi-structured discussions were held in a relaxed and informal atmosphere so that much of the shared information emerged from the natural flow of the conversation. Each discussion lasted about forty-five to sixty minutes. All discussions were tape recorded and transcribed, and pseudonyms are used to protect the anonymity of the respondents.

Both quantitative and qualitative methods were adopted in this research. A question form was designed and used during the in-depth interviews with the children of forced migration. The respondents were tape-recorded while they completed the standardized questionnaires and were encouraged to discuss their definitions of terms and responses to items in-depth. Furthermore analyses of results were derived from statistical chi-square test.

This study also focuses on whether actual journalism practices are sensitive to children's rights in news texts on children commonly associated with crime in Turkish media. In addition to this, the study attempts to make suggestions as to how journalism practices can be sensitive to children's rights.

Perceptions of stereotypes are important during analysis of the data attained from the semi-structured discussions. In media theory, serious under-representation of a particular group has been coined as "symbolic annihilation" (Gerbner \& Gross, 1976:101; Tuchman, Daniels \& Benet, 1978:9). Symbolic annihilation refers to the most profound inequities in "the spectrum of mediated representations of a social group" (Kielwasser \& Wolf, 1992:355).

\section{Anatomy of Anger: In-depth Interview and Results}

Research observed that the participants of in-depth interview hesitated to explain their ideas due to the fear from government. Research figures out those respondents are fed up with the violence on the streets. Freedom from anxiety is the only thing children are looking for.

The girls are looking for a hero to come and take them away from their current life conditions. They like going to school, doing homework, or reading book rather than participating in activities that isolated them such as taking care about their younger sister and brothers, cleaning out the house or being forced to get married by their families at the age of 14 .

The girls are learning about issues of femininity that takes place in the presence of others online, connected through chat rooms, and instant messaging in the case of accessing to internet. The girls said that they use the internet to flirt with guys in the virtual environment; because flirting with a guy outside can cause honor killing. "Honor" killings of women can be defined as acts of murder in which a woman is killed for her actual or perceived immoral behavior. Flirting with men, going out with men, refusing to submit to an arranged marriage, seeking a divorce can be described as an immoral behavior among this society.

Children do not have a separate room for studying and sleeping activities. There are not enough a furnished space in their homes like table, seat etc. It is observed that all furnished elements or equipments are available in some of the house but in a very poor quality. In terms of urban space level, they live in very bad conditions. There is not a regular infrastructure system Physical deprivation and low income levels prevent from living in a healthy environment. Houses are irregularly settled in an organic order (Akıner, 2010:24).

\subsection{Children are Speaking}

Can (17), was born in Bitlis (Eastern Anatolia), a high school pupil: 
"Yes, I'm throwing stone at police during protests and demonstrations for taking revenge of my friends who are arrested and jailed by security forces. The behaviors of police drive me throw stone to them. I don't trust mainstream media in Turkey. They don't realize the reasons of our anger. I would like to live in better conditions without discrimination and get a good education.

Koray (17), was born in Mersin, could not graduate from primary school because of being jailed:

"I was born in Mersin but I don't feel myself as coming from Mersin. I'm working as an apprentice in a repairman shop. Many years ago, I was jailed for two months because of throwing stone. After that the director of my primary school charged me with being supporter of terror organization and ended my studentship. Once upon a time I was dreaming about being advocate but now there is no dream and no future for me."

\section{Kamile (14), born in Mersin, a high school pupil:}

"The cops throw gas bombs in the district, enters with panzers, don't matter whether it's daytime or night. If you do such, the child would throw stone. We should take a sit and talk; we should think why those children throw stone. When the police throws gas bomb, we take our children inside, yet the gas diffuses into houses. Small children begin to vomit; we wash their faces, dab lemon on their faces. Although we try to stop them, when they experience such bad things, some children thought as if when they throw stone to a train, they throw it to the state; they react against state. They put stone to the railways so that they break the windows, to injure more people. To me, the child reifies the state that throws gas bomb to their strict with the train".

\section{Serhat (11) born in Bitlis, primary school pupil:}

"When I grow up, I will be a riot police. Because, when I grow, my child will also throw stone to the cops. At that time, then I will be nice to my child and to the other children like him/her".

\section{Eyşan (14) born in Mersin, a high school pupil:}

"We can't make friendship with the children from city center. When they learn where we live, they say "Do you live in stone-throwing street?" These places have such a bad reputation. I should solve our problems by the legal ways. I do not support the stone-throwing children. But mainstream televisions continue to show stone throwing children and it causes misperception of Kurdish children among the people from other cities of Turkey. The children living here need love."

\subsection{The Stereotypes Derived from the Results of the In-Depth Interviews Conducted with Children}

2.2.1.Definition of Stereotype

Many scholars have described the functions of the media in modern society. While they disagree on some details, they all agree on the media's pervasive influence on American society. In a 1948 essay that is often cited by other researchers, Harold Lasswell described the three major functions of communication as (Wilson, C.C., Gutierrez, F.F. and Chao, L.M., 2003:36):

a) Surveillance of the environment, disclosing threats and opportunities affecting the value position of the community and of the component parts with it; 
b) Correlation of the different part of society in responding to environment, and

c) Transmission of the social heritage from one generation to the next.

Most of these children have not physically experienced forced migration, but they have inherited the memories from previous generations and media propaganda. The children are particularly affected by propaganda. It is commonly agreed that television has become the source of the most broadly shared images and messages in history (Gerbner et al., 1986:48). Television's symbolic impacts in shaping or directing viewers' perceptions and behaviors toward others and society have been widely researched and documented in the United States as well as in other countries. Over the past 20 years, a large number of studies have found that those who spend more time watching television are more likely than light viewers to express views, beliefs, and assumptions that are congruent with television's depictions of life and society (Morgan and Rothschild, 1983: 34-35).

Media symbols are like computer screen icons. When using a computer, we have learned that when we see an icon and point to it, a click of the computer mouse will bring something we want to the screen. The symbol is the icon we see on the screen, and the stereotype is the function the computer brings to the screen we click on the icon. The media have their greatest effects when they reinforce and channel existing attitudes and opinions consistent with the psychological makeup of individuals and the social structure of the groups with which they identify, not when they try to change opinions (Wilson, C.C., Gutierrez, F.F. and Chao, L.M., 2003:46).

Prejudice may be defined as "a negative and partial attitude that prevents objective evaluation, aimed against an entire category of people, often an ethnic or racial minority" (Allport, 1979:26). In this sense, reporting of any kind should, naturally, be free of something "pre-judged." That is why there is a prominent relationship between prejudice and stereotypes. The term "stereotype" was formulated by Walter Lippmann in the early 1920s. He described the term as "the picture (of the world) that a person has in his/her head" (Lippman, 2004:43). Stereotypes are unreliable generalizations about all members of a group which do not recognize individual differences within the group. The term is generally applied to human beings, but it is quite possible to stereotype objects as well. In popular culture, both types of stereotypes are used. People are stereotyped around characteristics of age, sex, race, religion, vocation and nationality (Akıner, 2010:18). Objects can be stereotyped around characteristics of places such as: "Small towns are safe and clean," "In England, it rains all the time," and "A good house has a large lawn, big garage, and at least two bathrooms."

Stereotypes can be reinforced with images. Whether an individual is identified because of his/her gender, age, cultural heritage, economic status, sexual orientation, or physical disability, the instant visual message generally communicated about this person is often misleading and false. This is because, emotionally, pictures affect a viewer more than words alone do. Pictorial stereotypes often become misinformed perceptions that have the weight of established facts. These pictures can remain in a person's mind throughout a lifetime, and this is why a group of people with particular characteristics are thought to have their own way of life which never changes. As such, this is a phenomenon that deserves special attention. Also, the resultant sign reminds us of a virus. If it is not killed (or substituted) by another sign, it is capable of surviving years and years in hibernation, dormant but extant (Akıner, 2010:7). This sign may be used even 
long after the characteristic's strands have died away. The sign may enter films, art, cartoons or creative literature and be fossilized and ready to be revived in the future (Lester, 2006:92).

\subsubsection{Stereotypes of the Children}

\section{Stone}

People throwing stone to the police and the police throwing gas bomb to the protestors, used in protests, head broker, panzer, actuality, here's stone is shady too, an object thrown to the cop, followers of terrorist, thrown when there's war, a thing that the Kurds throw to the police, panzer.

\section{The Turk}

Nation, country, the Turk and the Kurd are fraternal, it is a people as well, fraternal, people who lives in downtown Mersin, enemy, human, our teacher is Turk as well but s/he isn't not enemy, very nice, anti-Kurd attitude, the fascism of the Turks, there are both good ones and bad ones, not all of them are same, it's animosity but whatever it is everybody is fraternal, everything belongs to them in this world, fraternal, I approach them as sibling, I don't discriminate, the oppressor people, barbarian, good person, honorable nation, identity, fraternity of the Kurds, people getting dressed in an obscene way.

\section{The Kurd}

Sibling of the Turks, people lives in our street, protest, fiesta, it is a people as well, the ones who throws stone to the panzer, there are both good ones and bad ones, not all of them are same, hospitable, good, all has spread to somewhere, the oppressed people, good person, the people who seeks its right, identity, who goes to mountains.

\section{Mersin}

Culture centre, pollution, Maiden's Castle, the policy of Turkey, hot, sea, citrus, protest, stone, police, orange, harbor, I don't know anywhere, drug, it's a free city because you can shout at whatever you want in the protests, my relatives, immigration.

\section{Picture of the Anger: Poll results \& Chi Square Test}

Within The research in which qualitative and quantitative methods were used, the Chi Square Test/Nonparametric Test was applied onto the poll results. For the Chi Square Test, which is the expression of a statistical test to prove non-quantitative qualitative variables, the hypotheses were established at first. Due to the established hypotheses Ho means, that "there is no difference between the observed value and the expected value". H1 means, that "there is a difference". 
Figure1. Ethnic Identity

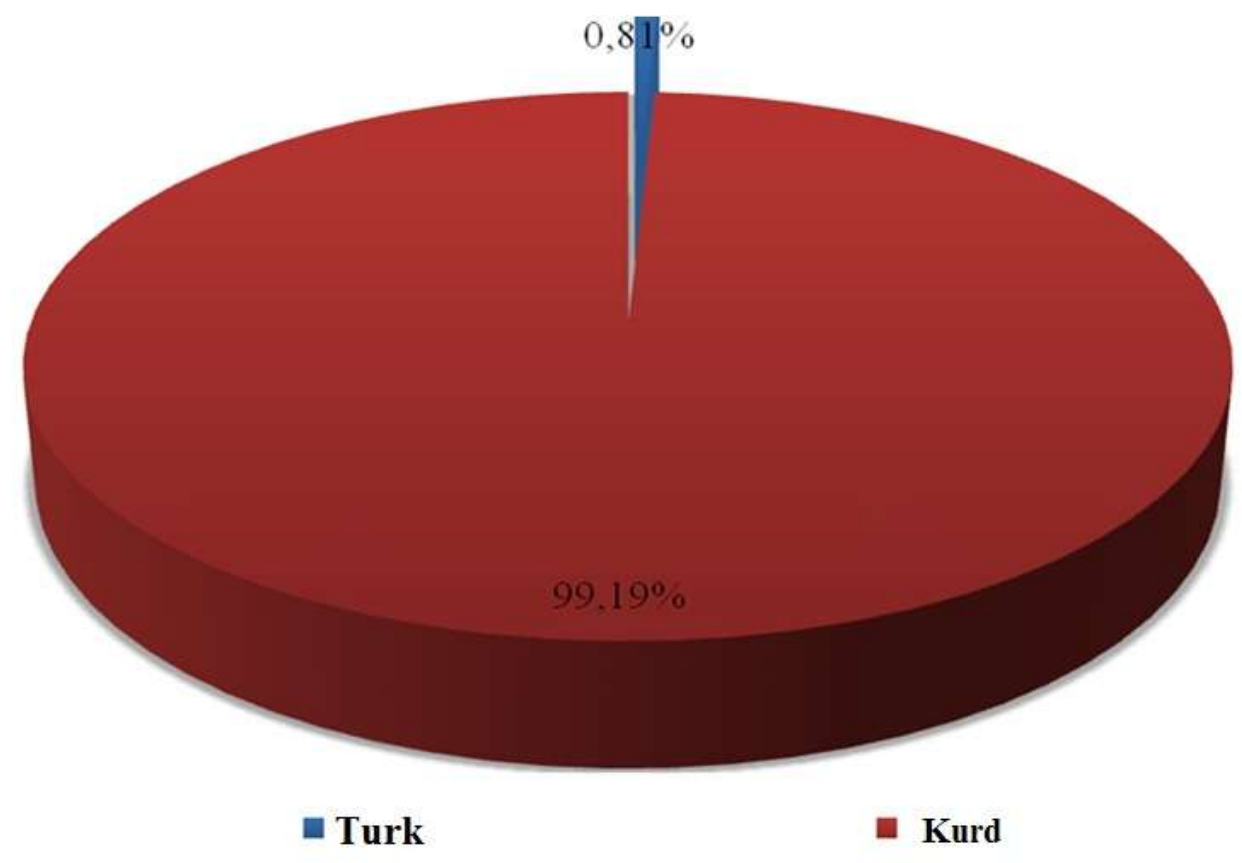

According to the picture when the ethnic identity of the people who joined the research has been asked, among 250 people, 2 of them identifies itself as Turk although s/he is originally Kurd; 248 of them identifies themselves as Kurd.

\section{Figure2. Religion and Sect}

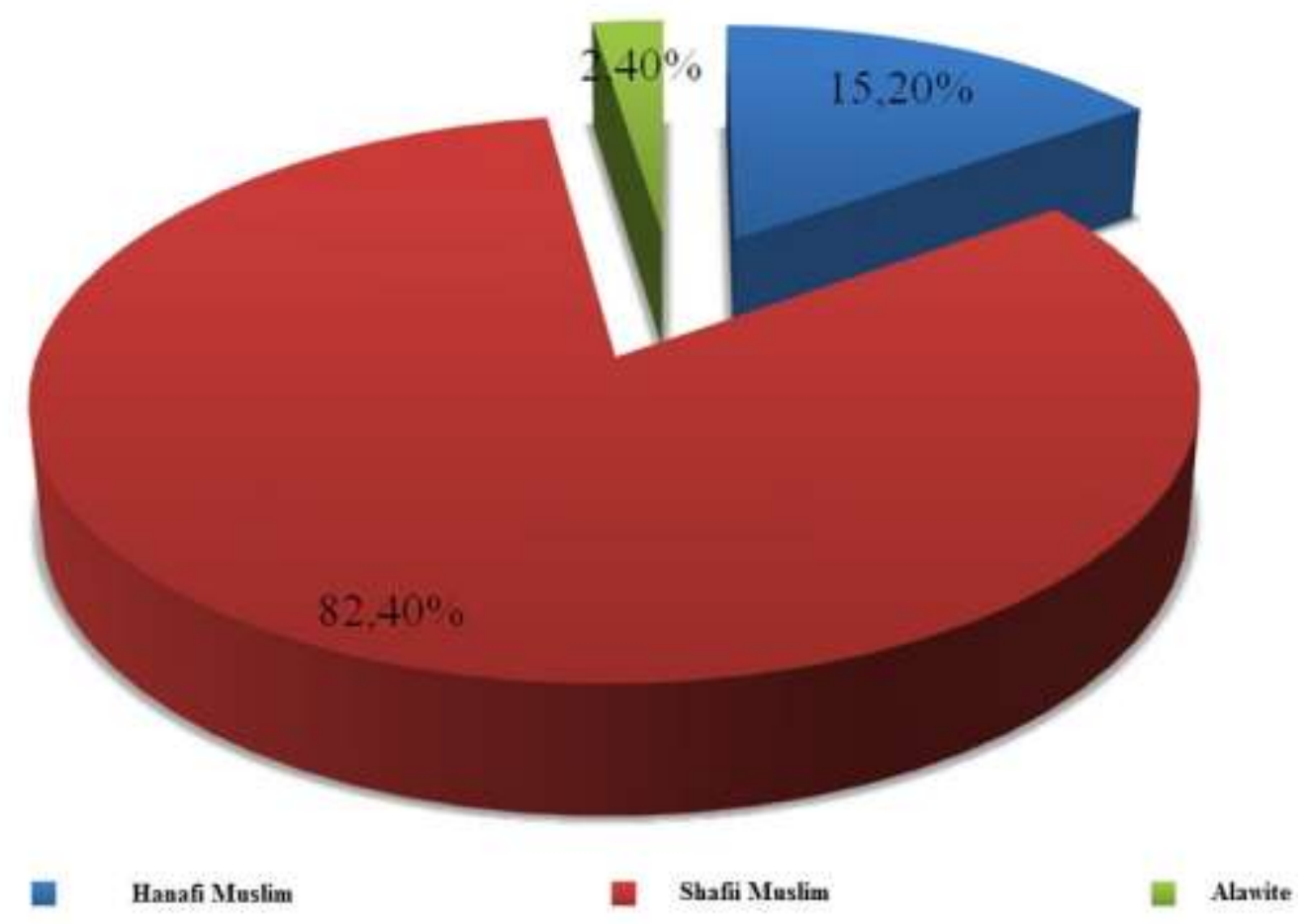


38 of the interviewers identify themselves as Hanafi Muslim and 206 of them as Shafii Muslim. On the other hand, 6 people who define themselves as Alawite, see Alewism as a form of life more than a belief. Though they experience the police violence, none of the Hanafi Muslims and Alawites accepts violence as a form of problem solving.

Figure3. Annual Income

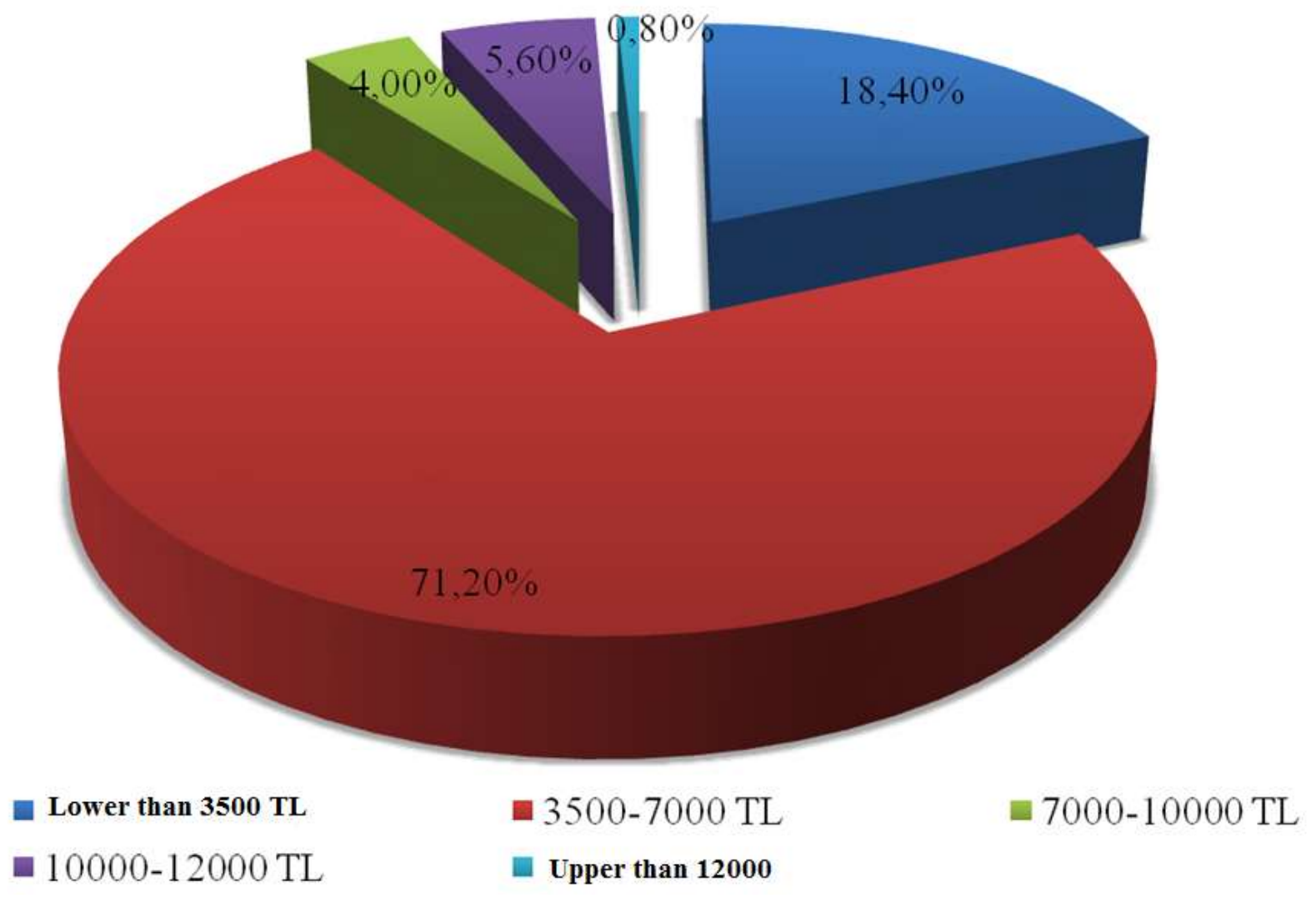

The annual income of 46 people's family among 250 people is under 3500 TL (1,553.35 EUR). 178 of the rest have an annual income between 3500 and 7000 TL (3,106.69 EUR), 10 of them have an income between 7000 and 10000 TL (4,438.78 EUR), annual income of 14 of them is between 10000 and 12000 (5,324.87 EUR), the income of 2 people is more than 12000 TL. 
Figure4. Would you like to go back to your village?

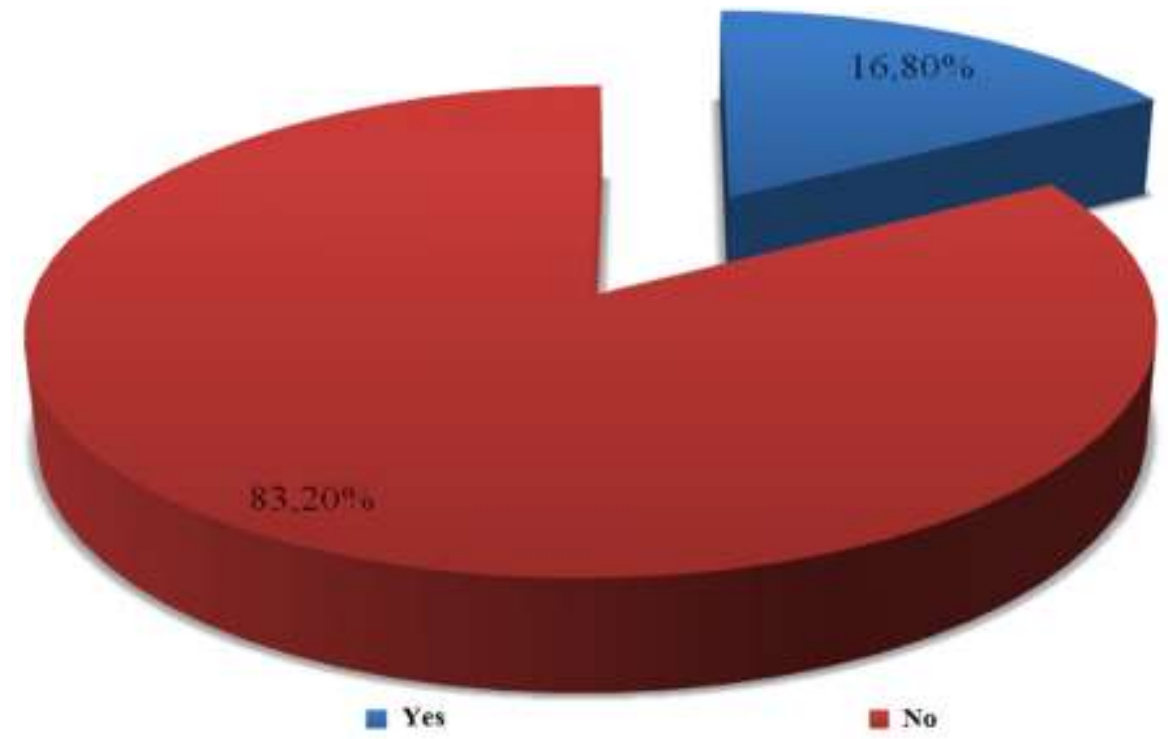

The 42 of ones who joined the research are ready to go back to their villages although their needs aren't met. The only thing they want is to have safe life conditions in their villages. The remaining 208 people don't want to go back to their villages in any condition. For them, Mersin is a city which is a little bit far away from the oppression of religion, tradition and cultural oppression.

Figure5. Is the reason of throwing stone to the police, police station and train political?
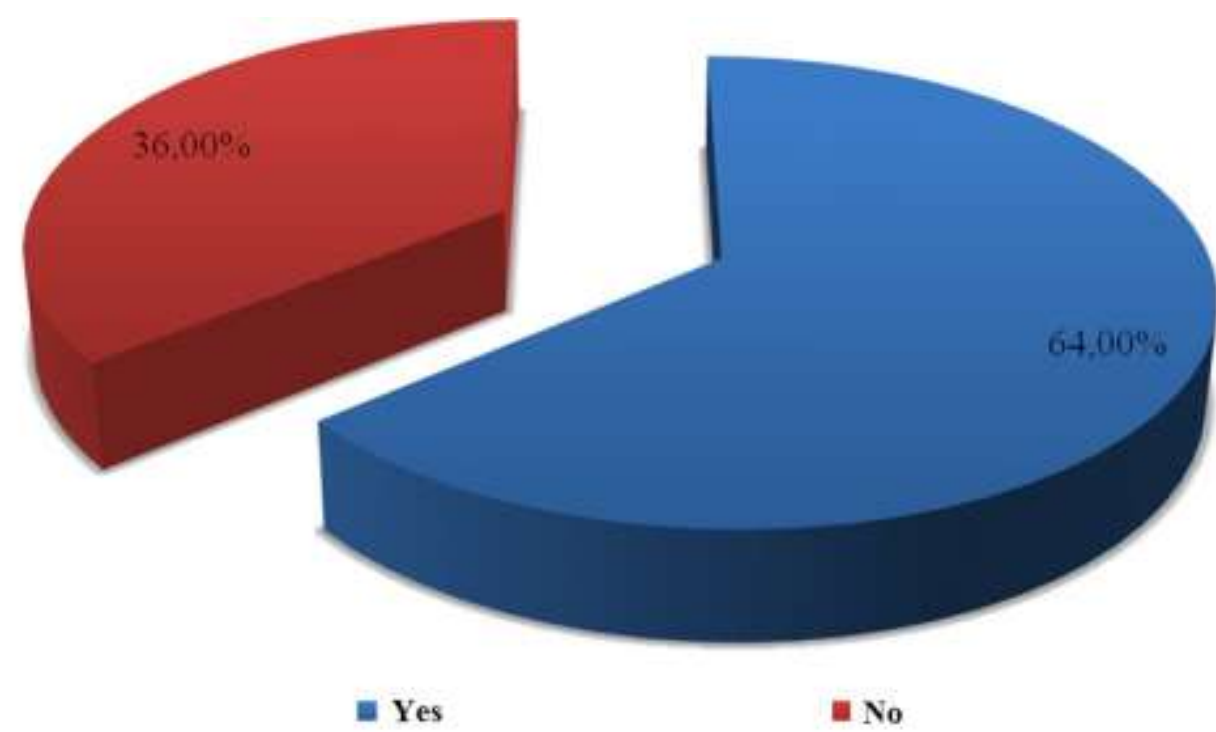

According to the 160 people joined the research, the reason of throwing stone to the police, police station and train is political. The news watched on TV is catalyzator of these kind of 
actions. According to these people, the news about the operations of the Turkish army against terrorist organization, any news about the country's agenda, any broadcast out of the stateowned Kurdish channels is fastens the so called protests.

Figure6. Do the national media represent you and your society fairly?

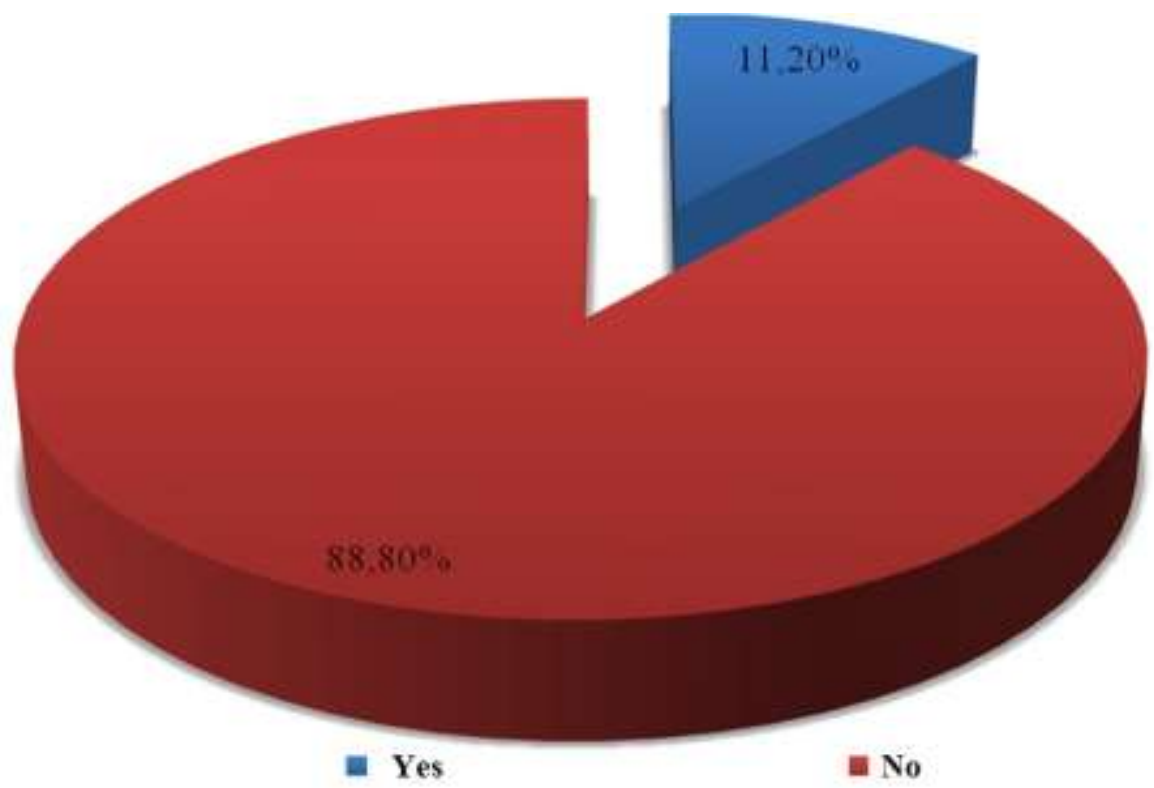

28 of the people who joined the research, believes that the national media represent him/her and the society fairly. But according to the remaining 208 people, national media don't represent the people who live in the outskirts of Mersin and emigrate here from South and Southeast of Anatolia fairly. These people don't trust the media.

Figure7. Did you have experience verbal or physical intervention of the police?

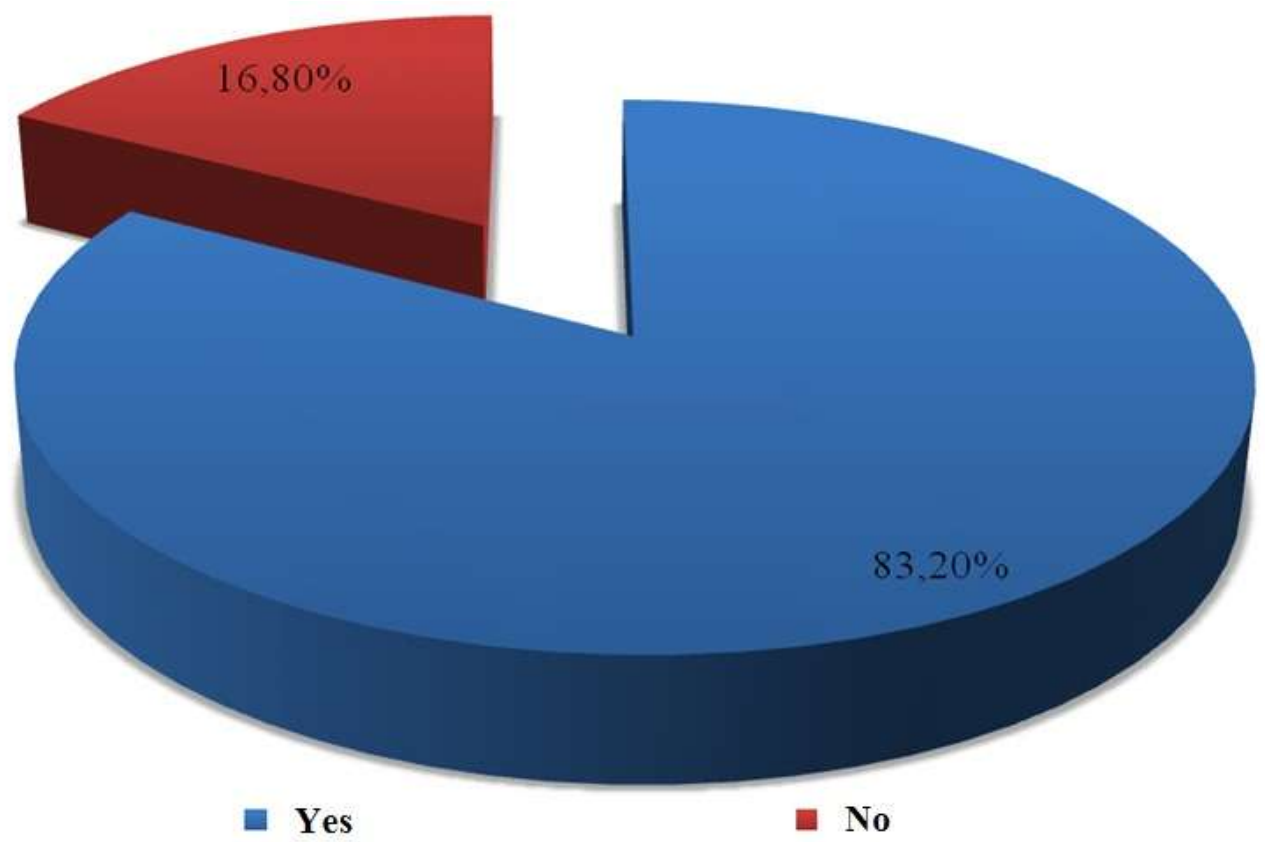


208 of the interviewers have experienced verbal or physical intervention of the police in the neighborhoods where they live. Although the remaining 42 people haven't experience such situations, they carry the fear of being the next.

Figure8. The reliability of the national newspapers

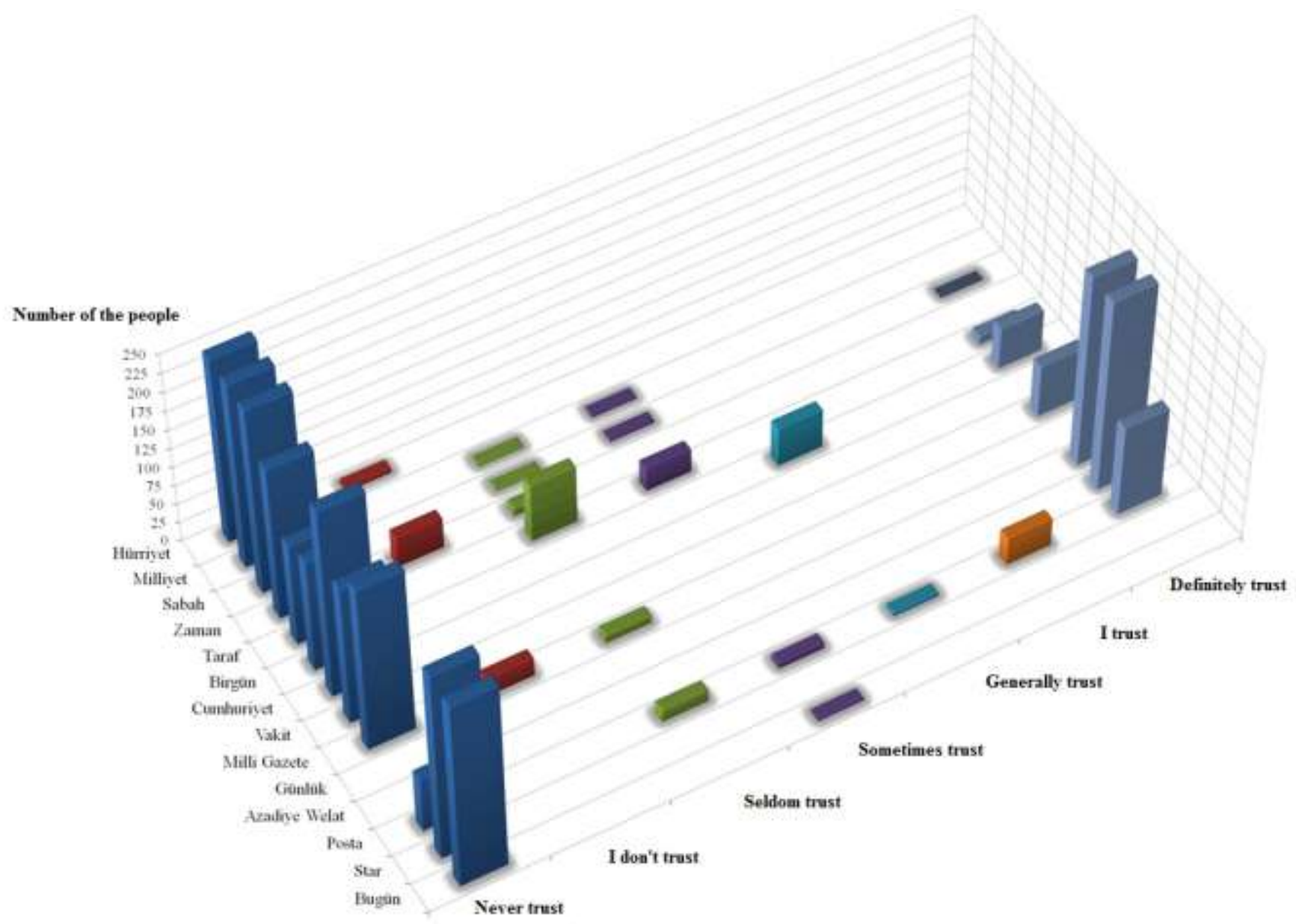

When the reliability of the national newspapers was asked among the interviewers, it was observed that the newspapers which were given 'high reliability' without doubt are Azadiya Welat and Gunluk -the later changes its name from time to time-, which are distributed upon an subscription system in the region. Azadiya Welat, which is the only newspaper published in Kurdish, and Gunluk find their readership in the districts in which the migrated population is dense upon a subscription system, they are not sold in usual ways (Akıner, 2010:173-174). 
Figure9. The reliability of the national TV channels

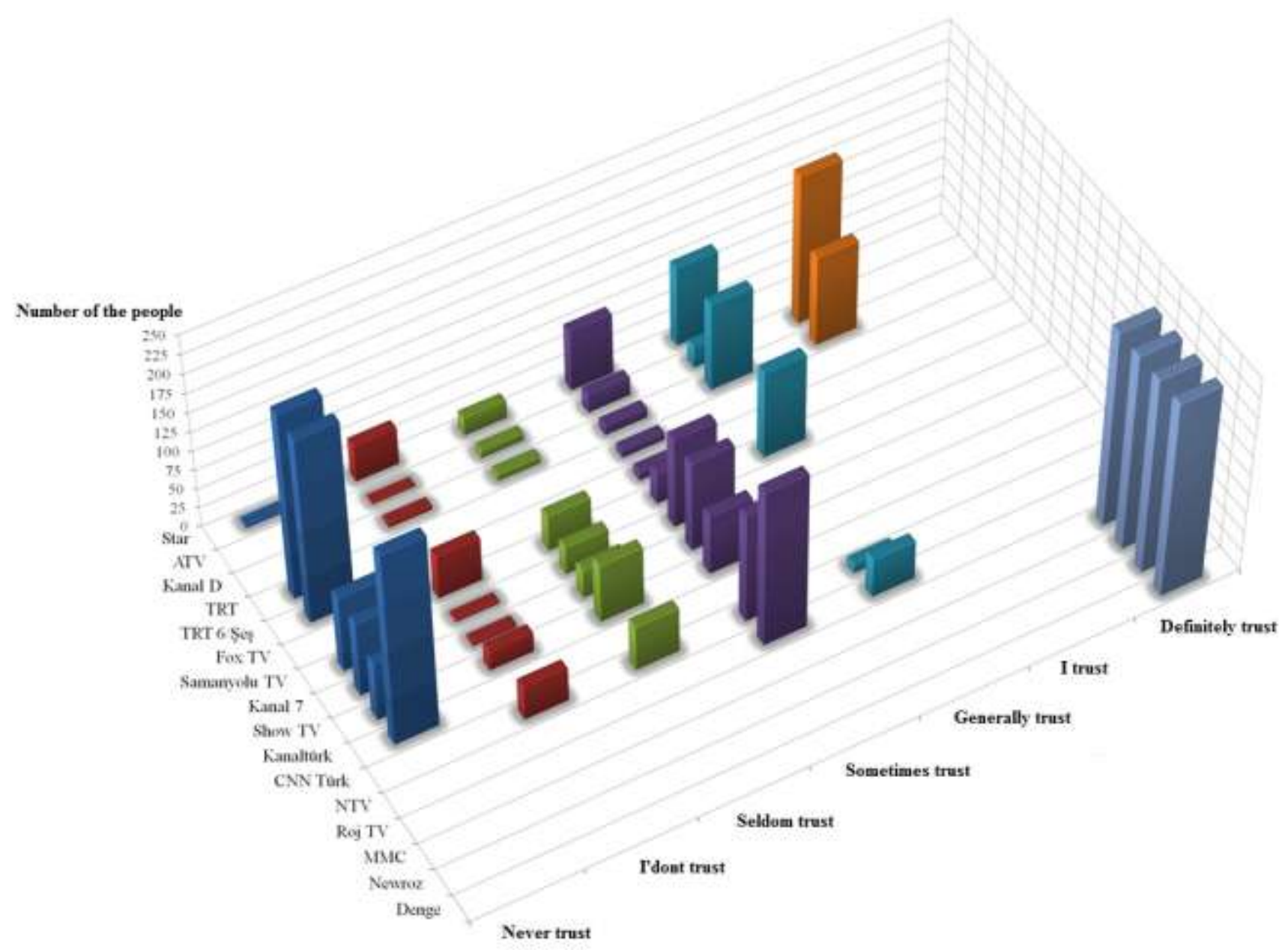

The participating 250 people trust mostly the TV channels such as Roj TV, MMC (Mesopotamia), Newroz and Denge. As it is the case with certain newspapers the people trust these TV channels without any doubt. Mothers do not want that their children watch the news on Roj TV due to the open exposition of violent scenes. But the interviews show that the children want to watch the news because of the violent scenes (Akıner, 2010:178-179). 


\section{Conclusion}

Most of the men and girls who participated in the poll advocate the view that throwing stones to the police is an action which is done unconsciously. To express it in a different way, these actions taking place in the district are turned into something like a computer games in which two opposing groups fight each other and one gains as much scores as one strikes.

Table2. Do you agree with the view that throwing stones onto the police is an action, which is done unconsciously?

\begin{tabular}{|l|l|l|l|}
\hline & Yes & No & Row Total \\
\hline Eastern Anatolia & 4 & 24 & 28 \\
\hline $\begin{array}{l}\text { The Black Sea } \\
\text { Region }\end{array}$ & 2 & 0 & 2 \\
\hline $\begin{array}{l}\text { Southeastern } \\
\text { Anatolia }\end{array}$ & 46 & 78 & 124 \\
\hline $\begin{array}{l}\text { Mediterranean } \\
\text { Region }\end{array}$ & 38 & 58 & 96 \\
\hline Aegean Region & 0 & 0 & 0 \\
\hline Marmara Region & 0 & 0 & 0 \\
\hline $\begin{array}{l}\text { Central Anatolia } \\
\text { Region }\end{array}$ & 0 & 0 & 0 \\
\hline Column Total & 90 & 160 & $\begin{array}{l}250<=\text { Grand } \\
\text { total }\end{array}$ \\
\hline
\end{tabular}

For place of the birth p: 0,000000000282

\section{$P$-value $=0,000000000282<0.05$ statistically extremely significant}

Most of the participants originate from the East and Southeast, but those born in the Mediterranean Region (Adana, Antalya and Mersin) do not agree with the view that throwing stones onto the police is an action, which is done unconsciously. The Chi Square test shows an interesting situation with this regard. The place of birth of individuals or the social environment in which they grow up has actually a greater influence on their behavior relative to their ethnic origin.

The more the annual income of the family is the more the children avoid violence and do not accept it. $12.80 \%$ of the participants are ready to murder for the sake of tradition. This group consisting of male children with an age of 14 years downward express without hesitating that if any issue is at stake regarding the honor of a women belonging to the family they will respond in "killing with a knife".

Due to the responses given to the poll, $83.20 \%$ of the participants were exposed to verbal or physical police intervention and gas bombs within the environment in which they live; $16.80 \%$ of the participants fear that they will be the next although they were not exposed to such situations. 
The data collected show how the press and the television have played an important role in the construction of the image. Television is the main source of information, which means it has a certain civic and social responsibility. The recent media should act due to the basic assumptions of the social responsibility theory in a pluralistic way, it should not forget that a conflict, a disagreement, a problem could involve more than one party (Akıner, 2004:225). The media should not reduce the conflict to two poles, should avoid dualism or dichotomies

The media should avoid overlooking other forces and factors influencing terror or violence while focusing on the geography of terror. From the point of view of the media the people living in the region as well as those generating policies and condemning violence in their own region are qualified as "enemies". The media should not fail to explain who are responsible for the actions taking place and why these escalate; it should avoid that the people of that region are qualified as "enemies".

Most of these children have not physically experienced forced migration, but they have inherited the memories from previous generations. The children born in Mersin embody a rage towards the past. Unselective police intervention raises the number of actors of the rage explosions in the suburbs day by day. Violence catalyzes again the process in which children are pushed into violence by means of propaganda. Mass media is especially influential upon children within this environment.

\section{REFERENCES}

AKINER, Nurdan (2010). Mersin'in Banliyölerinde Öfke Patlaması. İstanbul: Karakutu Yayınları.

AKINER, Nurdan (2004). Düşman Değiliz: 11 Eylül Saldırıları Ardından Amerikan Milliyetçiliği. İstanbul: Karakutu Yayınları.

ALLPORT, G. W. (1979). The nature of prejudice. New York: Perseus Books.

GERBNER, G. \& GROSS, L. (1976). Living with television: The violence profile. Journal of Communication, 26(2), pp. 99-172.

GERBNER, G., GROSS, L., MORGAN, M. and SIGNORIELLI, N. (1986). Living with Television: The Dynamics of the Cultivation Process. In Jennings Bryant and Dolf Zillman (eds.), Perspectives on Media Effects. New Jersey: Lawrence Erlbaum Association, Inc.

HOUSTON, C. (2001). Profane intuitions: Kurdish diaspora in the Turkish city. The Australian Journal of Anthropology, 12(1), 15-31.

KIELWASSER, A. P. \&Wolf, M. A. (1992). Mainstream television, adolescent homosexuality, and significant silence. Critical Studies in Mass Communication, 9(4), 350-73.

LESTER, P. M. (2006). Visual communication: Image with message. California: Thomson Wadsword.

LIPPMANN, W. (2004). Public opinion. New York: Dover Publications. 
MORGAN, M. \& ROTHSCHILD, N. (1983). Impact of The New Television Technology: Cable TV, Peers, and Sex-role Cultivation in the Electronic Environment." Youth \& Society, 15, 33-50.

Terör Tazminatları Ödensin (2005, May 16). CNNTürk. Retrieved November 7 2011, fromhttp://www.cnnturk.com/2005/turkiye/05/16/teror.tazminatlari.odensin/96 138.0/index.html.

TUCHMAN, G., DANIELS, A.K., \& BENET, J. (Eds.) (1978). Hearth and home: Images of women in the mass media. New York: Oxford University Press.

TÜİK (State Institute of Statistics) (2005), Genel Nüfus Sayımı 2000: Göç İstatistikleri (Census of Population 2000: Migration Statistics), Pub. No:2976, Ankara.

WILSON, C.C., GUTIERREZ, F.F. and CHAO, L.M. (2003). Racism, Sexism, and the Media: The Rise of Class Communication in Multicultural America. California: Sage Publication. 